\title{
„DYREKCYA ZAKONNEGO ŻYCIA”- NIEZNANY TRAKTAT Z 1744 ROKU O FORMACJI MONASTYCZNEJ NOWICJUSZEK BENEDYKTYŃSKICH
}

\section{Streszczenie}

W 1744 r. wileńska ksieni benedyktynek Joanna Sybilla Reytanówna opublikowała książkę Dyrekcya zakonnego życia. Chodziło o rodzaj praktycznego zbioru tekstów, przydatnego w całodziennej formacji nowicjuszek, stąd zawarto tu przede wszystkim konkretne nauki, dotyczące różnych sposobów doskonalenia życia w zakonie. Uzupełniały je odpowiednie modlitwy. O praktycznej funkcji książki świadczy także jej mały format, umożliwiający lekturę w każdej dostępnej sytuacji, tym bardziej że przewidziane ćwiczenia należało prowadzić w trakcie zajęć przygotowanych na cały dzień, zgodnie z rytmem życia w klasztorze. Podstawowa grupa zagadnień poruszanych w Dyrekcji zakonnego życia odnosiła się do konkretnych metod kształtowania życia we wspólnocie. Każda czynność miała odniesienie do sfery duchowej. Odrębnie uczono sposobu medytacji oraz prowadzenia rozmowy duchownej. Przewidziano także opis naśladowania cnót św. Benedykta, z podziałem na poszczególne miesiące, oraz ćwiczenia się w doskonałości (z podziałem na dni tygodnia). W traktacie J.S. Reytanówna odwoływała się zarówno do ideałów formacji kongregacji chełmińskiej, jak i do nauk oraz zwyczajów modlitewnych, propagowanych przez benedyktynów, dawnych spowiedników konwentu oraz innych autorów ascetycznych. W konsekwencji powstało unikalne kompendium, mające na celu pomoc w formacji zakonnej, a jednocześnie ukazujące sposób ujęcia ideału życia mniszego w wileńskiej wspólnocie.

Słowa kluczowe: benedyktynki wileńskie; Joanna Sybilla Reytanówna; nowicjat; formacja zakonna

\footnotetext{
* Jolanta Gwioździk - dr hab. literaturoznawstwa, prof. UŚ, Wydział Humanistyczny, Uniwersytet Śląski

e-mail: jolanta.gwiozdzik@us.edu.pl

https://orcid.org/0000-0002-2732-4115
} 
Przethumaczenie, opracowanie i wydanie w 1606 r. Reguly św. Benedykta „,Z reformacją porządków chełmieńskiego, toruńskiego, żarnowieckiego, nieświeskiego i inszych wszytkich w Królestwie Polskim tejże reformacji” miało na celu to,

Aby wszytkie klasztory Regułę S. Benedykta z takąż reformacja (...) w cale we wszystkim trzymały, zachowując jedność w odprawowaniu służby Bożej i ćwiczeniu duchownym, które dla większego postępku w zakonnej doskonałości jest ustanowione.

Ta edycja była wynikiem reformy polskich benedyktynek, prowadzonej pod kierunkiem ksieni żarnowieckiej Magdaleny Mortęskiej ${ }^{1}$. Chodziło o ustalenie i podanie wspólnych praw oraz zwyczajów ${ }^{2}$, do których zaliczała się jednolita formacja nowicjuszek, opisana w dodanym do reguły Porzadku nowicjatu z Reguły $S$. Benedykta zebranego i sporzadzonego do ćwiczenia duchownego i powierzchnego na ośm części główne rozdzielonego ${ }^{3}$. Przede wszystkim benedyktynki potrydenckie oddzieliły nowicjuszki od reszty wspólnoty. Uważano bowiem, że nowicjuszka jest to panna

nowy żywot zaczynająca, nowe reguly, nowe obyczaje, nowe miejsca, nowy habit, nowe ćwiczenia i wszystko nowe, zezwłocząc z siebie starego człowieka i cokolwiek jest ziemskiego odcinając, wszystkie chwasty z serca4.

\footnotetext{
${ }^{1} \mathrm{Na}$ temat okoliczności powstania reguły zob. M. Borkowska, Między tradycja a powrotem do źródet. Szesnastowieczne modele odnowy życia zakonnego w Polsce, w: Fermentum massae mundi, red. N. Cieślińska, P. Rudziński. Warszawa 1990, s. 12 i nast., M. Borkowska, Potrydencka wersja Reguly św. Benedykta, w: Za przewodem Ewangelii. Profesja monastyczna, Tyniec 1986, s. 249262; taż, Two Attempts at Self Government of Feminine Religious Institutes in Poland, „Studia Monastica", 23 (1981) s. 169-179. Biogram ksieni M. Mortęskiej zob. M. Borkowska, Słownik polskich ksień benedyktyńskich, Niepokalanów 1996, s. 104-105.

${ }^{2}$ Reguła Świętego Oyca Benedicta. : Z łacińskiego przettumaczona, y z Reformacya porzadków, chetmieńskiego, Toruńskiego, Żarnowieckiego, Nieświeskiego, y inszych wszytkich w Krolestwie polskim teyźe Reformacyey y Reguly S. Benedikta, ktore teraz sa y napotym ziednoczone będa, Klasztorow Panieńskich. Władza stolice apostolskiey, przez Jasnie Wielmożnego Oyca, X. Wawrzynca Gębickiego, z taski Bożey Biskupa Chetmieńskiego, Pomezaniey administratora etc. Roku pań. 1605 potwierdzona. Na końcu położone krotko zebrane laski y odpusty przez uczestnictwo tymże Zakonnicom od ś. pamięci Clemensa PP. VIII darowane wiecznie. W Krakowie: U Wdowy Jakuba Sybeneychera, 1606, s. 259-260. Następne edycje pochodzą z lat 1635, 1647 i 1737.

${ }^{3}$ Porzadek nowicjatu z Reguly S. Benedykta zebrany i sporządzony do ćwiczenia duchownego i powierzchnego na ośm części główne rozdzielony w: Reguła Świętego Oyca Benedicta..., s. 154261. Przedrukowano także Porządek nowicjatu w 1635 r. oraz jako edycję samoistną wydawniczo w 1737 r. w Sandomierzu. O popularności tekstu w środowisku zakonnym świadczy jego adaptacja (z niewielkimi zmianami) na potrzeby norbertanek, przygotowana w 1613 r. przez Gabriela Kiekczewskego, Sposób życia Panien do zakonu się mających : wedtug Reguty Augustyna Świętego, [b.m.w., b.w.] 1613. Opis edycji zob. J. Gwioździk, Kultura pisma i ksiązki w klasztorach żeńskich dawnej Rzeczypospolitej XVI-XVIII wieku, Katowice 2015, s. 289.

${ }^{4}$ Rozmyślania na początku ćwiczenia nowicjackiego sporządzone Roku Pańskiego 1778 dnia 1 miesiąca sierpnia Za staraniem [...] Beaty Nikorowiczówny konwentu lwowskiego WW PP Bene-
} 
Nowicjat był miejscem próby powołania (należało wypełnić nie tylko przykazania, ale i dochować rad ewangelicznych), zakonu (,który doświadcza i upatruje, którzy się zgodzą albo nie do budynku duchownego") i czasem sprawdzenia własnych sił (w unikaniu pokus, przezwyciężaniu przeciwności, wytrwaniu w powołaniu $)^{5}$.

Nowicjat trwał dwa lata i dzielił się na kilka etapów, przy czym zalecano, by pierwsze pół roku ćwiczenia były prowadzone w grupie panien świeckich, które w klasztorze pobierały nauki. Przed przyjęciem do nowicjatu upewniano się, czy panna zna i pojmuje „,wszystkie powinności chrześcijańskie”, potrafi dobrze czytać (po polsku i po łacinie) oraz pisać i śpiewać (a przynamniej solmizować) ${ }^{6}$. Pierwszy etap formacji trwał dwa miesiące. Wówczas ustalano, czy nowicjuszka jest sposobna do podjęcia życia zakonnego, m.in. badano, czy jest świadoma trudów życia we wspólnocie, sprawdzano jej stan zdrowia, uwzględniano opinię o niej w społeczeństwie, a także dobrowolność powołania. Istotna była ponadto analiza charakteru panny, bowiem dla niektórych ,żyć bez zakonu pożyteczniej niż abo klasztor onemi i zgromadzenie zarazić, abo ciężar, któremu sprostać nie są sposobne ze szkodą dusze ich a z niepokojem zgromadzenia na nie nieroztropnie włożyć"7. Po dwu miesiącach odbywał się egzamin. Pytano o stałość powołania, akceptację „ciężaru” reguły

Jeśli się jej nie uprzykrza droga tak ostra w umartwieniu i w posłuszeństwie, a ścisła w milczeniu i w ubóstwie, i jakiego ducha czuje w sobie przeciwko zakonowi tak ścisłemu $\mathrm{w}$ ubóstwie i w posłuszeństwie, przeciwko tak ustawicznemu ćwiczeniu zwierzchnemu przez pracą, a wnętrznemu przez straż w myślach, ustawiczną walkę z pokusami ${ }^{8}$.

Następnie nowicjuszki przenoszono do odrębnego pomieszczenia i wyznaczano im mistrzynię nowicjatu. Jej zadanie uznawano za szczególnie istotne, bowiem „, ćwiczenia nowicjuszek wszytek postępek duchowny całego żywota i nadzieja zakonu pewna zawisła". Mistrzyni powinna poznawać skłonności i postęp w życiu wewnętrznym każdej panny. Uczyła je przede wszystkim prowadzenia życia według reguły św. Benedykta, począwszy od sposobu zachowania w klasztorze po ćwiczenia duchowne:

Gdy się panna mistrzyni z swojemi nowicjuszkami w tych rzeczach powierzchnych, tak jako się tu mówi, porządną stanie, zarazem też w samym prostowaniu ich do samego duchowieństwa i do samej doskonałości zakonnej do tych rzeczy osobliwie serca ich zniewolić usiłować ma się uczyć, aby się próżnowania wnętrznego i powierzchnego nie tylko strzegły, ale je jako pewnego posła wszech złości w wielkiej nienawiści miały ${ }^{10}$.

dyktynek nowicjatu Mistrzyni, Lwowska Narodowa Naukowa Biblioteka Ukrainy im. Wasyla Stefanyka, rkps 118, k. 17.

${ }^{5}$ Tamże, k. 16.

${ }^{6}$ Porzadek nowicjatu, s. 160-161.

${ }^{7}$ Tamże, s. 160.

${ }^{8}$ Tamże, s. 201-202.

${ }^{9}$ Tamże, s. 163.

${ }^{10}$ Tamże, 166. 
Przede wszystkim za niezbędne uznawano „wielką żarliwość do cnót zakonnych”, wyrażonych w składanych ślubach, ,wesołą mężność" w walce ze złymi nałogami i pokusami oraz wierność w zachowaniu pożądanej postawy. Celem, do którego dążyły nowicjuszki, była „wolność ducha”, który

wzgardziwszy wszystkim i sobą samym, jednoczy się z Bogiem, chcąc nieprzerwanie zażywać $\mathrm{z}$ wielką kontentacyją dusze pokoju onego, którego świat dać nie może i nigdy nie tracić części onej, która w niebie zostaje z człowiekiem na wieki, a nikt od niego oddalić jej nie może ${ }^{11}$.

Drugi etap formacji obejmował sześć miesięcy. Rozpoczynało go sprawdzenie, czy nowicjuszki pamiętają i dobrze pojmują otrzymane wcześniej nauki. Ćwiczenia następnie obejmowały przede wszystkim dokładne poznanie reguły św. Benedykta, a także lekturę określonych ksiąg, „pilne i gorące rozmyślanie” oraz liczne umartwienia. Ważnym sposobem pracy wewnętrznej były rozmowy duchowe. Po sześciu miesiącach ksieni i wyznaczona siostra przeprowadzały indywidualny egzamin, który obejmował sprawdzenie „sposobności” do zakonu nowicjuszki, opis jej wad i zalet („cnót”), przewidziano także bezpośrednią rozmowę z panną ${ }^{12}$.

Trzeci etap nowicjatu liczył cztery miesiące, podczas których kolejny raz czytano regułę św. Benedykta „,Z wykładem”"13, a czas ten kończył egzamin, w trakcie którego badano zakres jej zrozumienia, gotowość do życia według ślubów zakonnych i stopień przygotowania do profesji (m.in. przez miesiąc rozmyślano o życiu zakonnym $)^{14}$. Decyzje o dopuszczeniu do niej podejmowała ksieni wraz wyznaczonymi siostrami. Po profesji panny miały „ćwiczyć się (...) w postępku do doskonałości chrześcijańskiej przez cały rok”, a mistrzyni miała je „prowadzić (...) do więtszej znajomości i miłości Pana Boga, w wielkim uspokojeniu"15, a także do lepszego przygotowania do życia we wspólnocie. W tym czasie „samem ich czytaniem, rozmyślaniem i ćwiczeniem duchownym z wielką ochotą bez utęsknienia zabawi, i dlatego ich ani do zgromadzenia, ani do chóru nie przypuści"16, za wyjątkiem dni świątecznych. Przewidziano ponadto specjalne przygotowanie do konsekracji.

W dziele formacji nowicjuszek największa odpowiedzialność spoczywała na mistrzyni nowicjatu oraz ksieni jako matce duchowej benedyktyńskiej wspólnoty. Najczęściej z ich inicjatywy opracowywano materiały służące przygotowaniu panien do życia zakonnego. W 1744 r. „Dla lepszej Wielebnych Panien Nowicjuszek wygody” ukazała się praca Dyrekcja zakonnego życia ${ }^{17}$, wydana 17 września tego

${ }^{11}$ Tamże, s. 167-168.

${ }^{12}$ Opis egzaminu zob. tamże, s. 218-225.

${ }^{13}$ Chodziło o komentarze, do najbardziej znanych należała praca J. Torquemady, zob. W.O. y P. Jana z Turecrematu, kardinała S. Sixta na świętego Benedikta Opata Regułę wyktad. W Krakowie: W Drukarni Andrzeja Piotrkowczyka, 1607.

${ }^{14}$ Porzadek nowicjatu, s. 231.

${ }^{15}$ Tamże, s. 232.

16 Tamże, s. 233.

${ }^{17}$ Dyrekcya zakonnego życia. [b.m.w., b.w.], 1744. Jeden egzemplarz zachował się w klasztorze SS. Benedyktynek w Żarnowcu. Druk nie jest notowany przez bibliografie. 
roku ,za staraniem" ksieni wileńskiej benedyktynek J.S. Reytanówny (ksieni w latach 1741-1746) ${ }^{18}$. Wcześniej była ona przeoryszą w tym klasztorze, przy ówczesnej ksieni Magdalenie Sybilli Pacównie (urząd sprawowała w latach 1704-1741), która wznowiła działalność edytorską konwentu wileńskiego: w 1709 r. opublikowała pracę benedyktyna Romana Zawadzkiego Metal na taksie i próbie Opatrzności Boskiej (w 1745 r. edycję powtórnie wydała jej następczyni, J.S. Reytanówna), a w 1724 r. opłaciła druk antologii modlitw św. Gertudy ${ }^{19}$. Ewentualne dalsze prace nakładcze ksieni M.S. Pacówny utrudnił pożar z 1737 r., który w takim stopniu uszkodził część klasztoru i kościoła, że konieczny był kosztowny remont zabudowań. Joanna S. Reytanówna kontynuowała odbudowę, a jednocześnie w tej trudnej dla benedyktynek sytuacji zdecydowała się na publikację 17 września 1744 r. Dyrekcji zakonnego życia „,dla lepszej panien nowicyuszek wygody”20. Dowodzi to nie tylko jej starań o życie wewnętrzne klasztoru ${ }^{21}$, lecz także może świadczyć o potrzebie takiego opracowania ${ }^{22}$. Chodziło o rodzaj praktycznego kompendium, przydatnego w całodziennej formacji nowicjuszek, stąd zawarto tu przede wszystkim konkretne nauki, dotyczące różnych sposobów doskonalenia życia w zakonie. Uzupełniały je odpowiednie modlitwy. O praktycznej funkcji książki świadczy także jej format $\left(64^{\circ}\right)$, umożliwiający noszenie woluminu przy sobie i lekturę w każdej dostępnej sytuacji, tym bardziej że przewidziane ćwiczenia należało prowadzić $\mathrm{w}$ trakcie zajęć przygotowanych na cały dzień, zgodnie z rytmem życia w klasztorze ${ }^{23}$.

${ }^{18}$ Joanna Reytanówna (Rejtanówna) była córką Franciszka, podczaszego mozyrskiego. Nowicjat odbyła w 1695 r., profesję w 1697 r., przyjęła imię Sybilla. W latach 1739 i 1741 była przeoryszą. Należała do Bractwa Najświętszego Serca, założonego w 1705 r. przez ksienię S. Pacównę. Zmarła 31 sierpnia 1746 r. Biogram zob. M. Borkowska, Leksykon zakonnic polskich epoki przedrozbiorowej, t. 3, Warszawa 2008, s. 132.

${ }^{19}$ R. Zawadzki, Metal na taksie i próbie Opatrzności Boskiej siła ważacy albo moc i skutki metalu krzyża Ojca i Patriarchy Benedykta przeciwko morowemu powietrzu. W Wilnie: w Drukarni Akademickiej Societatis Jesu, 1709; Gertuda św. Niebo na ziemi albo strzeliste akty i afekty. W Wilnie: [b.w.], 1724. O inicjatywach edytorskich benedyktynek wileńskich zob. Gwioździk, Kultura pisma i książki, s. 246-249. W pracy tej nie uwzględniono wspomnianej antologii.

${ }^{20}$ Dyrekcja zakonnego, s. 146.

${ }^{21}$ Pochlebnie o postawie ksieni pisał Stanisław Kmita w dedykacji Kazania na dzień Wielkiego Patriarchy i Fundatora S. Benedykta Na rekwizyzję wielkiej honoru S. Oyca Promotorki [...] Sybilli Reytanowny Zakonu S. O. Benedykta Xieni konwentu wileńskiego do druku podane. W Wilnie: W Drukarni Akademii Societatis Jesu, 1745.

${ }^{22}$ Jak wspomniano, ksieni J.S. Reytanówna wznowiła w 1745 r. pracę Ch. Zdrowskiego, w tym samym roku także dedykowała Benedyktowi Tyzenhauzowi kazanie Stanisława Kmity Wielki luminarz Benedykt święty cnotami i cudami nad słońce jaśniejszy..., W Wilnie: w Drukarni Societatis Jesu, 1745.

${ }^{23}$ W Porządku nowicjatu (s. 175-177) przyjęto następujący podział dnia 24 - jutrznia z laudesami („wielka i mała”), odprawiona „z ceremoniami i uczciwością, tak jako w chórze powinny zwyczaj jest”; 5-6 - rozmyślanie; 6-8 - godziny kanoniczne „wielkie i małe” (prima, tercja, sexta, nona), dwie msze św. (komunia raz w tygodniu oraz w święta); 8-8.15 - porządek w celi; 8.15-ok. 11 - nauka pisania (dla nowych nowicjuszek), pisanie (po dwu miesiącach nowicjatu), rozmowa z mistrzynią, kapituła (we wtorki i piątki); ok. 11 - obiad; 12-13 - duchowa rozmowa; 13-13.30 - 
Podstawowa grupa zagadnień poruszanych w Dyrekcji zakonnego życia odnosiła się do konkretnych metod kształtowania życia we wspólnocie. Formacja dotyczyła poszczególnych sfer życia, realizowanych w przestrzeni klasztoru: na chórze, w celi, refektarzu, w trakcie modlitwy liturgicznej i prywatnej, w drodze do kościoła, w czasie mszy św. Każda czynność miała odniesienie do sfery duchowej. Odrębnie uczono sposobu medytacji oraz prowadzenia rozmowy duchownej. Przewidziano także opis naśladowania cnót św. Benedykta, z podziałem na poszczególne miesiące, oraz ćwiczenia się w doskonałości (z podziałem na dni tygodnia). W podręczniku przyjęto następujący układ:

1. Określenie fundamentu zakonnego życia: „wyniszczenie samej siebie”, „wyrzeczenie się własnej woli” w odniesieniu do czynności codziennych, jak sen czy posiłek (s. 1-2).

2. Modlitwa do Boga Ojca, zanoszona za pośrednictwem Chrystusa, z powoływaniem się na zasługi Jego męki. Bogu ofiarowywano sprawę konkretnej nowicjuszki, dziękując za wszelkie doznane dobrodziejstwa, „ku pożytkowi całego Kościoła i wszystkiej zwierzchności” (s. 2-3).

3. Symboliczne odniesienie poszczególnych czynności do Męki Chrystusa: „Drogi albo chodzenie co znaczy” (s. 3-7), „Ubieranie co znaczy” (s. 7-13), „Przy stole... jak się sprawować” (s. 13-26).

4. „Intencja rozporządzona pacierzy kapłańskich” (s. 26-30).

5. „Godziny męki Pańskiej” (s. 30-41).

6. Akt „mimo kościoła idąc” (s. 42)

7. Ofiarowanie pięciu i trzech ,pacierzy” (s. 42-45)

8. Sposób rozmyślania (s. 45-48).

9. Znaczenie „pacierzy kapłańskich” (s. 49-61).

10. Rozmowa duchowna (s. 62-78).

11. Modlitwa przed liturgią godzin (s. 78-79).

12. „Ćwiczenie się w cnotach”, z podziałem na dni tygodnia (s. 80-81).

13. Modlitwy: przy „kropieniu wodą święconą” (s. 81-82), przed komunią (s. 82), poranna (s. 82-83).

14. Wykład „pacierzy kapłańskich” i modlitwa (s. 84-111).

15. „Ćwiczenie w cnotach św. Benedykta”, z podziałem na miesiące (s. 111-119).

16. "Ćwiczenie się w cnotach”, z podziałem na dni tygodnia (s. 119-145).

Informacja o przeznaczeniu książki (s. 145-146).

Dyrekcja zakonnego życia dzieliła nauki odnoszące się do czynności zewnętrznych oraz duchowych. Do pierwszych należał sposób zachowania w drodze na chór, gdzie odprawiano określone godziny kanoniczne, w refektarzu i w celi. Do drugich można zaliczyć sposób odprawiania godzin kanonicznych, rozważania i modlitwy.

zapoznanie z czytaniami na nieszpory i jutrznię; 13.30-14.30 - nauka śpiewu; 14.30 - czytanie książki duchowej; 15 - nieszpory, kompleta, rozmyślanie (pół godziny), czas wolny; 17-18 - kolacja, rozmowa duchowna; 18-19 - litania, punkty do rozmyślania, rachunek sumienia, czas milczenia; 19 - pobyt w celi; 19.30 - sen. 
Poszczególne czynności dnia codziennego odnoszono do opisów ewangelicznych, związanych z Męką Chrystusa (zob. tab. 1).

Tabela 1. „Drogi albo chodzenie co znaczy”

\begin{tabular}{|c|c|c|}
\hline $\begin{array}{l}\text { Droga opisana } \\
\text { w Dyrekcji za- } \\
\text { konnego życia }\end{array}$ & $\begin{array}{l}\text { Odniesienie do wydarze- } \\
\text { nia z Ewangelii }\end{array}$ & Opis w Ewangeliach \\
\hline $\begin{array}{l}\text { na jutrznię } \\
\text { i z jutrzni }\end{array}$ & $\begin{array}{l}\text { przejście do Ogrójca } \\
\text { i przez Cedron (s. 3) }\end{array}$ & $\begin{array}{l}\text { „Wtedy przyszedł Jezus z nimi do ogrodu, } \\
\text { zwanego Getsemani” (Mt 26,36), ,To powie- } \\
\text { dziawszy Jezus wyszedł z uczniami swymi } \\
\text { za potok Cedron. Był tam ogród, do którego } \\
\text { wszedł On i Jego uczniowie” (J 18,1) }\end{array}$ \\
\hline $\begin{array}{l}\text { wyjście i powrót } \\
\text { z primy, tercji } \\
\text { i sexty }\end{array}$ & $\begin{array}{l}\text { zaprowadzenie Chrystusa } \\
\text { do arcykapłanów Annasza } \\
\text { i Kaifasza (s. } 3 \text {-4) }\end{array}$ & $\begin{array}{l}\text { „Wówczas kohorta oraz trybun razem ze } \\
\text { strażnikami żydowskimi pojmali Jezusa, zwią- } \\
\text { zali Go i zaprowadzili najpierw do Annasza. } \\
\text { Następnie Annasz wysłał Go związanego do } \\
\text { arcykapłana Kajfasza.” (J 18,12-13, 24) }\end{array}$ \\
\hline do refektarza & $\begin{array}{l}\text { Jezus idący do „piwnicy” } \\
\text { (s. 4) }\end{array}$ & $\begin{array}{l}\text { "Od Kajfasza zaprowadzili Jezusa do preto- } \\
\text { rium. A było to wczesnym rankiem" (J } 18,28)\end{array}$ \\
\hline na nonę i z nony & $\begin{array}{l}\text { Jezus przed Piłatem i He- } \\
\text { rodem (s. 4-5) }\end{array}$ & $\begin{array}{l}\text { „Teraz całe ich zgromadzenie powstało } \\
\text { i poprowadzili Go przed Piłata. Tam zaczęli } \\
\text { oskarżać Go” (Łk 23,1), „A gdy się upewnił, } \\
\text { że jest spod władzy Heroda, odesłał Go do He- } \\
\text { roda, który w tych dniach również przebywał } \\
\text { w Jerozolimie” (Łk 23,7) }\end{array}$ \\
\hline $\begin{array}{l}\text { na nieszpory } \\
\text { i z nieszporów }\end{array}$ & $\begin{array}{l}\text { przejście do Piłata i droga } \\
\text { do biczowania (s. 5) }\end{array}$ & $\begin{array}{l}\text { „Wówczas Piłat wziął Jezusa i kazał Go ubi- } \\
\text { czować” (J 19,1) }\end{array}$ \\
\hline na wieczerzę & „droga po sukienkę” (s. 5) & $\begin{array}{l}\text { „A żołnierze uplótłszy koronę z cierni, włożyli } \\
\text { Mu ją na głowę i okryli Go płaszczem purpu- } \\
\text { rowym" (J 19,2) }\end{array}$ \\
\hline $\begin{array}{l}\text { do kościoła } \\
\text { i z kościoła }\end{array}$ & $\begin{array}{l}\text { Chrystus idący „do koro- } \\
\text { nowania” oraz „na ratusz” }\end{array}$ & $\begin{array}{l}\text { „Gdy więc Piłat usłyszał te słowa, wyprowa- } \\
\text { dził Jezusa na zewnątrz i zasiadł na trybunale, } \\
\text { na miejscu zwanym Lithostrotos, po hebrajsku } \\
\text { Gabbata” (J 19,13) }\end{array}$ \\
\hline $\begin{array}{l}\text { na kompletę } \\
\text { i z komplety }\end{array}$ & $\begin{array}{l}\text { sąd Piłata oraz niesienie } \\
\text { krzyża na Kalwarię }\end{array}$ & $\begin{array}{l}\text { „Wtedy więc wydał Go im, aby Go ukrzyżo- } \\
\text { wano. A On sam dźwigając krzyż wyszedł na } \\
\text { miejsce zwane Miejscem Czaszki, które po } \\
\text { hebrajsku nazywa się Golgota” (J 19,16-17) }\end{array}$ \\
\hline przed snem & Jezus ukrzyżowany & $\begin{array}{l}\text { „Tam Go ukrzyżowano, a z Nim dwóch } \\
\text { innych, z jednej i drugiej strony, pośrodku zaś } \\
\text { Jezusa” (J 19,18) }\end{array}$ \\
\hline
\end{tabular}

Źródło: opracowanie własne na podstawie Dyrekcja zakonnego życia.

Do codziennie powtarzanych, zwykłych czynności należało także przygotowanie się do snu i ubieranie się. Św. Benedykt kwestii stroju poświęcił rozdział 55 reguły, a w rozdziale 22 zaznaczył, że mnisi powinni spać ubrani i przepasani pa- 
sem lub sznurem. W klasztorach tzw. kongregacji chełmińskiej strój nowicjuszek regulował Porzadek nowicjatu, w którym odrębny rozdział traktował „O odzieniu nowicjuszek i ich westiarjej, także o dobrach, które do klasztoru wnoszą" ${ }^{24}$. W nowicjacie obowiązywał specjalny ubiór:

Acz Reguła nie wspomina w jakim odzieniu nowicjuszki chodzić mają, jednak duchownym prawem Can. sanctimonialis virgo, Dist. 23 cap. 24 rzecz jest przystojna, aby w habicie tegoż zakonu nowicjuszki chodziły, w którym stałość swoję Panu Bogu trzymać obiecują. Przetoż nowicjuszki tej reformacji w sukienkach czarnych i w rąbeczkach białych według dawnego zwyczaju i sporządzenia Deklaracji rozdziału 55 także i Benedyktyny rozdziału 22 chodzić będą.

W Dyrekcji zakonnego życia każdemu z elementów stroju mniszego nadawano określone znaczenie. Takie odniesienie symboliczne było znane i szczególnie rozbudowane w przypadku szat liturgicznych. Kapłan w ofierze mszy św. reprezentuje bowiem osobę Jezusa, działa w Jego imieniu, a szaty liturgiczne mają ukazywać, co znaczy „przyoblec się w Chrystusa” (,trzeba porzucić dawnego człowieka (...) odnawiać się duchem w waszym myśleniu i przyoblec człowieka nowego, stworzonego według Boga, w sprawiedliwości i prawdziwej świętości”, Ef 4,2226). W symbolice stroju nawiązywano do treści pasyjnych, eklezjologicznych lub eucharystycznych, a poszczególnym elementom ubioru zgodnie z tym nadawano określone znaczenie ${ }^{25}$, np. stuła była symbolem więzów, którymi skrępowano Jezusa w czasie biczowania, mogła także oznaczać jarzmo Chrystusa lub władzę kapłańską ${ }^{26}$. W wydanym przez ksienię wileńską Marcybellę Grużewską (urząd pełniła w latach 1668-1682) Pektoraliku duchownym autorstwa benedyktyna Chryzostoma Zdrowskiego również symbolicznie opisano szaty celebransa, np. w humerale należało widzieć zakrycie oczu, w pasie, manipularzu i stule - powrozy krępujące Chrystusa, w ornacie - Jego szatę itp. ${ }^{27}$ Te odniesienia pasyjne wykorzystano następnie w Dyrekcji zakonnego życia, gdzie koszula nowicjuszki miała być „szyderską szatą Pana Jezusa”, sznurówka oznaczała Jego „wewnętrzne bóle”, habit - „sukienkę”, pas i „zapinanie ręki” - powrozy, którymi krępowano Chrystusa, wiązano Jego ręce, szkaplerz symbolizował krzyż, czepek, na którym upinano wszystkie elementy przybrania głowy - „rwanie za włosy Pana Jezusa", śmiertelnik i zawiązka - zawiązanie Mu oczu, zatyczka miała przywodzić na myśl Weronikę, strojnik z czapką - cierniową koronę, a rąbeczek (tj. welon) oznaczał całun ${ }^{28}$.

${ }^{24}$ Tamże, s. 169.

${ }^{25}$ L. Rotter, Ubiór czy kostium? Znaczenie i funkcja strojów zakonnych, Kraków 2015, s. 44.

${ }^{26}$ Tamże, s. 44-45.

${ }^{27}$ Ch. Zdrowski, Pektoralik Duchowny dla Panien Zakonnych Pod Reguta Swiętego Benedykta Zyiacych [...] do druku za dozwoleniem Starszych Podany. W Wilnie : w Drukarni Akademickiej Societatis Jesu, 1681, s. 78-80.

${ }^{28} \mathrm{O}$ elementach stroju benedyktynek zob. Borkowska, Życie codzienne polskich klasztorów żeńskich w XVI-XVIII wieku, Warszawa 1996, s. 147-153; Rotter, Ubiór czy kostium, s. 105-139. 
Nakładaniu poszczególnych elementów stroju kapłańskiego towarzyszyła odpowiednia modlitwa ${ }^{29}$. W Dyrekcji zakonnego życia przewidziano również specjalne oracje (przejęte z Pektoralika duchownego ${ }^{30}$ ), które należało wypowiadać przy wkładaniu i zdejmowaniu odzieży oraz myciu się. Dla Ch. Zdrowskiego mycie w sferze duchowej symbolizowało oczyszczenie z „nieprawości” (por. Ps 51), zdjęcie habitu i szkaplerza - odrzucenie ,starego człowieka” (1 Kol 9-10), a ubranie habitu i welonu było jak włożenie szaty godowej ${ }^{31}$. Teksty modlitw w Dyrekcji zakonnego życia również nawiązywały do obrazu szaty „godowej”, wybielonej we krwi (czyli miłości Ukrzyżowanego) Baranka (zob. Ap 7,14). Jaśniejące szaty przywołują ponadto obraz uczty weselnej:

Powinniśmy na te święte zaślubiny Oblubieńca i Oblubienicy przybywać w szacie godowej, to znaczy mając zrozumienie miłości najgłębszej. Jest to konieczne, abyśmy - jeżeli nie założymy szaty weselnej, to znaczy godnego pojmowania miłości - nie byli wyrzuceni z owej uczty weselnej w zewnętrzne ciemności, to jest w zaślepienie niewiedzy ${ }^{32}$.

Zakonnice jako oblubienice Chrystusa powinny przygotować się do udziału w uczcie niebieskiej (czyli dostąpić chwały wiecznej) przez ,zwleczenie starego człowieka złości" (symbolizowane przez zdejmowanie habitu) i przyobleczenie się „w nowego człowieka” Jezusa Chrystusa: „wy wszyscy, którzy zostaliście ochrzczeni w Chrystusie, przyoblekliście się w Chrystusa" (Ga 3,27). Jednocześnie tylko Bóg może człowieka „oczyść z nieprawości” (por. Ps 51,4), przyoblec „suknią miłości” (wkładanie habitu) i ustroić oblubienicę, tak by mogła Mu się podobać ,jako najlepiej” i „wdzięczną [tj. piękną, miłą] się stawić [tj. pokazać się]” (symbol wkładana welonu) ${ }^{33}$. Tylko On wreszcie mógł „obmyć” i „oczyścić z nieprawości" (modlitwa w czasie mycia). Należało ponadto prosić Boga o niewinność, czystość i godne zachowanie ślubów zakonnych (symbolika pasa ${ }^{34}$ ), a także o naśladowanie Jego posłuszeństwa i cierpliwości świętej, by „drogą zakonnej obserwancji (...) zajść do wiecznej chwały".

Symboliczny wymiar przybierały również czynności nowicjuszki związane z posiłkiem. Zasady zachowania w refektarzu regulowała reguła oraz tzw. zwyczajniki, Porządek nowicjatu zaś dokładnie ustalał sposób postępowania nowicjuszek. Przewidziano na ich potrzeby „odrębną kuchenkę abo komin niemały i insze miejsca do porządku domowego sporządzone i wszytkie w jednym zawarciu pod kluczem mistrzyniej zamknione"35. W refektarzu stół dla profesek był odrębny, mogła z nimi siedzieć tylko mistrzyni i kantorka. Czas obiadu i wieczerzy rów-

${ }^{29}$ Rotter, Ubiór czy kostium, s. 44.

${ }^{30}$ Zdrowski, Pektoralik Duchowny, s. 56-57.

${ }^{31}$ Dokładniej na ten temat zob. J. Gwioździk, Benedyktynka doskonała (Pektoralik duchowny 1681), w: Monastycyzm XV-XVIII wieku. Tradycja średniowieczna wobec wyzwań nowożytnego humanizmu, red. M.T. Gronowski, P. Urbański, Warszawa 2016, s. 80-114.

${ }^{32}$ Grzegorz Wielki, Komentarz do „Pieśni nad pieśniami”, w: Teologia duchowości, http://duchowosc.uksw.edu.pl/czytelnia/gwiazda/grzegorz-wielki/ (dostęp: 10.11.2016).

${ }^{33}$ Dyrekcya zakonnego, s. 12, Zdrowski, Pektoralik Duchowny, s. 57.

${ }^{34}$ Więcej na ten temat zob. Rotter, Ubiór czy kostium, s. 105-106.

${ }^{35}$ Porzadek nowicjatu, s. 169. 
nież należało wykorzystać na ćwiczenie pasyjne, przy czym zalecenia w Dyrekcji zakonnego życia miały charakter zarówno wskazówek medytacyjnych, jak i praktycznych uwag, dotyczących sposobu zachowania się (zob. tab. 2). Były one adresowane do wszystkich nowicjuszek, zwłaszcza dla sióstr, które w danym tygodniu były wyznaczane do służenia wspólnocie.

Tabela 2. „Przy stole ... jak się sprawować”

\begin{tabular}{|c|c|c|}
\hline Czynność & Opis w Porzadku nowicjatu & Opis w Dyrekcji zakonnego życia \\
\hline $\begin{array}{l}\text { Wezwanie na } \\
\text { posiłek (,,do } \\
\text { stołu dzwo- } \\
\text { nią") }\end{array}$ & $\begin{array}{l}\text { „Skoro wtory raz do obiadu abo } \\
\text { do wieczerzy zadzwonią, pójdą } \\
\text { z panną mistrzynią swą z układnemi } \\
\text { obyczajmi, statecznie, nie prędko, } \\
\text { a wychodząc z mieszkania swego, } \\
\text { skłonią się ku kościołowi, z krót- } \\
\text { kim westchnieniem do Pana Boga, } \\
\text { mówiąc te abo tym podobne słowa: } \\
\text { Panie, weźmi sobie serce moje a daj } \\
\text { mi twoje” (s. 183) }\end{array}$ & $\begin{array}{l}\text { Rozważanie: } \\
\text { „(...) wspomnij na Pana Jezusa na } \\
\text { krzyżu wiszącego, którego ukrzy- } \\
\text { żowawszy wszyscy się do domów } \\
\text { swoich porozchodzili, a jedna tylko } \\
\text { Maryja została z świętym Janem } \\
\text { Ewangelistą i świętą Marią Mag- } \\
\text { daleną, chcąc jaką posługę Jemu } \\
\text { uczynić” (s. 14-15). } \\
\text { Praktyka: } \\
\text { I ty też najmilsza siostro życz sobie } \\
\text { tego, abyś jaką posługę odprawić } \\
\text { siostrom mogła ” (s. 15) }\end{array}$ \\
\hline $\begin{array}{l}\text { Odmówienie } \\
\text { psalmu }\end{array}$ & $\begin{array}{l}\text { (psalm pokutny De profundis clamavi } \\
\text { ad te Domine) }\end{array}$ & $\begin{array}{l}\text { Rozważanie: } \\
\text { „wspomnij sobie na śmierć Pana } \\
\text { Jezusa, prosząc, aby przez obfitą } \\
\text { śmierć swoję raczył się zmiłować } \\
\text { nad umarłemi, a zwłaszcza nad do- } \\
\text { brodziejami naszemi” (s. 15-16) } \\
\text { Praktyka: } \\
\text { modlitwa „za umarłe” siostry (s. 15) }\end{array}$ \\
\hline $\begin{array}{l}\text { Wejście do } \\
\text { refektarza } \\
\text { w określonym } \\
\text { porządku, } \\
\text { błogosławień- } \\
\text { stwo i zajęcie } \\
\text { miejsca przy } \\
\text { stole }\end{array}$ & $\begin{array}{l}\text { „Wszedłszy do refektarza, skłonią się } \\
\text { wszystkie i staną na miejscu swoim } \\
\text { w porządku do benedykcyjej i tak } \\
\text { z drugiemi za stół usiędą" (s. 183) }\end{array}$ & $\begin{array}{l}\text { Rozważanie: } \\
\text { „Siadając do stołu tak sobie mów } \\
\text { i myśl, jakobyś na górze Kalwaryj- } \\
\text { skiej, gdzie Pan Jezus jest ukrzyżo- } \\
\text { wany, tam z Najswietszą Maryją pod } \\
\text { krzyżem stała” (s. 16) } \\
\text { Praktyka: } \\
\text { „benedykcyją nabożnie mów” (s. 16) }\end{array}$ \\
\hline $\begin{array}{l}\text { Zachowanie } \\
\text { przy stole }\end{array}$ & $\begin{array}{l}\text { „Sposób zachowania się u stołu ten } \\
\text { im opisujemy: wstydliwie spuszczone } \\
\text { oczy u stołu mieć, lekcyjej z przygo- } \\
\text { towaniem serca słuchać” (s. 182) }\end{array}$ & $\begin{array}{l}\text { Rozważanie: } \\
\text { „Lekcya u stołu znaczy owe słowa } \\
\text { Pańskie na krzyżu mówione do Naj- } \\
\text { świętszej Panny, albo też milczenie } \\
\text { onej pod krzyżem stojącej, gdy }\end{array}$ \\
\hline
\end{tabular}




\begin{tabular}{|c|c|c|}
\hline & & $\begin{array}{l}\text { myśliła, jakoby go z krzyża zdjąć } \\
\text { mogła” (s. 20) } \\
\text { Praktyka: } \\
\text { „I ty też najmilsza siostro na to pa- } \\
\text { miętając, powinnaś u stołu zachować } \\
\text { milczenie, spokojne siedzenie i oczu } \\
\text { swych spuszczenie, abyś u stołu } \\
\text { jako anioł siedziała, drugim do tego } \\
\text { przykład dając" (s. 20-21) }\end{array}$ \\
\hline $\begin{array}{l}\text { Spożywanie } \\
\text { posiłku }\end{array}$ & $\begin{array}{l}\text { „Chcemy nad to, aby przy świętych } \\
\text { obyczajach pomienionych, ćwiczyła } \\
\text { ich też po letku mierności jedzenia } \\
\text { (...) Abowiem sytość i delikackie abo } \\
\text { zapalające potrawy, zakonnym nie } \\
\text { należą nigdy, gdyż posilenia tylko } \\
\text { ciała szukać a ukochanie smaku do } \\
\text { Chrystusa oblubieńca swego obracać } \\
\text { są powinne” (s. 182). }\end{array}$ & $\begin{array}{l}\text { Rozważanie: } \\
\text { „Nasycenie się pokarmem i napo- } \\
\text { jem: znaczy, iż Pan Jezus na krzyżu } \\
\text { umarły daje nasycenie wszelkiemu } \\
\text { stworzeniu” (s. 19) }\end{array}$ \\
\hline Umycie rąk & $\begin{array}{l}\text { „wody w lawaterz naleje, ręcznik } \\
\text { biały w niedzielę i śrzodę zawiesi” } \\
\text { (s. 180) }\end{array}$ & $\begin{array}{l}\text { Rozważanie: } \\
\text { „Gdy ręce umywasz, wspomnij } \\
\text { sobie, iż wielkiej czystości Pan po } \\
\text { tobie potrzebuje” (s. 23) }\end{array}$ \\
\hline $\begin{array}{l}\text { Wyjście z re- } \\
\text { fektarza }\end{array}$ & $\begin{array}{l}\text { „A po skończeniu psalmu, serdecz- } \\
\text { ne westchnienie z krótkiemi słowy } \\
\text { uczynią, te abo tym podobne słowa } \\
\text { mówiac: Panie Jezu, mieszkaj w ser- } \\
\text { cu moim” (s. 183) }\end{array}$ & $\begin{array}{l}\text { Rozważanie: } \\
\text { „Gdy od stołu wstajesz, uważaj } \\
\text { przyjście Józefa z Nikodemem, któ- } \\
\text { rzy przyszedłszy pokłonili się Panu } \\
\text { Jezusowi na krzyżu wiszącemu, gdy } \\
\text { go mieli z krzyża zdejmować” (s. 22) } \\
\text { Praktyka: } \\
\text { „nie powinnaś u stołu rozmawiać ani } \\
\text { od niego wstawać aż za dozwole- } \\
\text { niem starszej” (s. 22) }\end{array}$ \\
\hline $\begin{array}{l}\text { Droga do celi } \\
\text { i kościoła }\end{array}$ & $\begin{array}{l}\text { „Po gratias w takowej że się skrom- } \\
\text { ności do swego miejsca mieszkania } \\
\text { wrócą, a przed kościołem upadszy } \\
\text { na kolana, powinną cześć i chwałę } \\
\text { Panu Bogu oddadzą, mówiąc Laudate } \\
\text { Dominum do coelis” (s. 183). }\end{array}$ & $\begin{array}{l}\text { Praktyka: } \\
\text { „Idąc do kościoła nabożnie rozwa- } \\
\text { żaj, jakobyś Pana Jezusa na krzyżu } \\
\text { jeszcze będącego pozdrawiała, żeby } \\
\text { się zmiłował nad dobrodziejami, } \\
\text { a nam odpuścił grzechy przy stole } \\
\text { przez ludzką ułomność nieostrożnie } \\
\text { popełnione” (s. 25-26) }\end{array}$ \\
\hline
\end{tabular}

Źródło: opracowanie własne na podstawie Dyrekcja zakonnego życia.

${ }^{a}$ Por. zapis „Lectia u stołu znaczy one słowa Pańskie na krzyżu mówione. Abo też milczenie Naświętszey Panny pod krzyżem stojącey, która myśliła, jakoby syna swojego z krzyża zdjąć mogła. A ty też namilsza siostro milczeć masz u stołu", w: Zabaw, cwiczenia, y niektórych Modlitw dla Panien Zakonnych krotko zebranych część pierwsza. W Krakowie : Bazyli Skalski Drukował, 1610, s. nlb. 32. 
Specjalne nauki kierowano do sióstr, które co tydzień pełniły w refektarzu służbę. Wyznaczona siostra powinna rano rozpalić w piecu, a po mszy św. wysprzątać wyznaczoną na posiłki izbę, wynieść śmieci, przygotować ręczniki i wodę w lawaterzu ${ }^{36}$. W trakcie posiłku usługiwała siostrom; wówczas zbierając naczynia, powinna mówić: „daj Boże, abym dobrze sumnienie rozbierała i duszę oczyściła, abyś Ty sam w niej mieszkał" ${ }^{\prime 3}$. Rozważanie powinno także towarzyszyć nakładaniu i zdejmowaniu ubrania „do służenia”, gdy należało prosić miłosiernego Boga o „przyobleczenie” w Jego miłość i łaskę oraz umiejętność zwalczenia (dokładnie „zwleczenia”) wszystkich złych nałogów i niedoskonałości ${ }^{38}$. Odrębne pouczenie było przeznaczone dla lektorki, która powinna prosić o duchowy pożytek z lektury dla słuchających i samej siebie. Modliła się zatem następująco: „otwórz Panie oczy i serce moje ku przystojnemu czytaniu”39. Tekst modlitwy (z niewielkimi zmianami) został skopiowany z kompendium dla „panien zakonnych" ${ }^{40}$. Stamtąd pochodzi także symboliczne odniesienie sposobu zachowania przy stole do wydarzeń pasyjnych.

Podstawą życia monastycznego był udział w liturgii, wyznaczający rytm codziennej modlitwy wspólnotowej. Uznawano, że w

Kościele Bożym żadne[go] urzędu nie masz (...) coby abo potrzebą, abo dostojnością to Kapłańskie Oficjum przechodzić abo się z nim słusznie zrównać mogło. Abowiem odprawieniem godzin jako przystoi Pana Boga błagamy, do miłosierdzia skłaniamy, anielski urząd sprawujemy, niebieską ojczyznę uweselamy, szatany hamujemy ${ }^{41}$.

Z tego też względu należało odpowiednio przygotować się do oficjum, przede wszystkim przez skupienie (by nie wyjść na sercu „rozsypanym”), wyraźne wymawianie słów, a zwłaszcza świadomość obecności Boga: „pilnie i nabożnie będziesz się modlił, tak żebyś abo do słów, które mówisz, abo do sensu ich jeśli rozumiesz, abo do tego z kim mówisz, to jest do tego, który jest twórcą wsze[go] stworzenia, atencją obracal"42. W Pektoraliku duchownym Ch. Zdrowski poszczególne godziny kanoniczne wiązał z etapami drogi krzyżowej ${ }^{43}$, podobny sposób rozważania wykorzystano w Dyrekcji zakonnego życia.

Na każdy dzień tygodnia wyznaczono intencję, z jaką powinno się odprawiać liturgię godzin (s. 26-30). W niedzielę w czasie modlitwy należało pamiętać o dobrodziejstwach Boga (czyli darze życia, Odkupieniu, darach wiary, powołania, zdrowia), w poniedziałek - o dobrych przyjaciołach, krewnych i powinowatych (a także o wrogach), we wtorek - o rodzicach i dobrodziejach oraz o duszach w

\footnotetext{
${ }^{36}$ Tamże, s. 180-181.

${ }^{37}$ Dyrekcya zakonnego, s. 23

${ }^{38}$ Tamże, s. 23-24.

${ }^{39}$ Tamże, s. 25.

${ }^{40}$ Zabaw, cwiczenia, s. nlb. 32.

${ }^{41} \mathrm{~J}$. Alvarez, O żywocie zakonnym jako ma być świętobliwie prowadzon. Kraków : Drukarnia Mikołaja Loba, 1613, s. 43. Por. także: „Wszystkie rzeczy czas mają, także każda godzina z oficjum czasu swego potrzebuje, w którym od Pana jako dług posługę wyciaga", tamże, s. 45.

42 Tamże, s. 58.

${ }^{43}$ Omówienie zob. Gwioździk, Benedyktynka doskonała.
} 
czyśćcu, w środę proszono o cnoty sprzyjające osiągnięciu doskonałości zakonnej, w czwartek miano na uwadze rozszerzenie wiary, „wykorzenienie” herezji, zgodę w Kościele i potrzeby własnego klasztoru, modlitwy w piątek ofiarowano za grzechy własne i cudze, a w sobotę chodziło o powodzenie Zakonu św. Benedykta, zachowanie reguły i ślubów, a także odpowiednie rządy przełożonych w klasztorze. Symboliczne znaczenie pasyjne nadawano poszczególnym czynnościom, wymienianym w układzie dnia, wyznaczanym przez porządek godzin kanonicznych (zob. tab. 3).

Tabela 3. „Pacierze kapłańskie co znaczą?”

\begin{tabular}{|c|c|}
\hline $\begin{array}{l}\text { Czynności w porządku } \\
\text { oficjum }\end{array}$ & Scena biblijna i symbolika pasyjna \\
\hline $\begin{array}{l}\text { Jutrznia } \\
\text { pierwszy dzwonek }\end{array}$ & pojmanie Chrystusa w Ogrójcu \\
\hline drugi dzwonek & pytanie Chrystusa: „Kogo szukacie” (s. 49) \\
\hline droga na chór & $\begin{array}{l}\text { zdanie Judasza: „Otóż jest imajcie go, a wiedźcie go ostrożnie” } \\
\text { (s. 49) } \\
\text { Zachowanie: pilne odmawianie jutrzni, trwanie w obecności } \\
\text { Chrystusa: „trzymajże go mocno a nie wypuszczaj od siebie” } \\
\text { (s. 51) }\end{array}$ \\
\hline pierwszy nokturn & $\begin{array}{l}\text { pierwsza modlitwa Chrystusa i budzenie św. Piotr: „Pietrze } \\
\text { śpisz? nie mogłeś jednej godziny ze mną czuć?” (s. 51) }\end{array}$ \\
\hline drugi nokturn & druga modlitwa Chrystusa w Ogrójcu \\
\hline trzeci nokturn & $\begin{array}{l}\text { trzecia modlitwa Chrystusa, gdy ,krwawym potem się pocił” } \\
\text { (s. 52) }\end{array}$ \\
\hline Ewangelia & anioł mówi Jezusowi o pełnieniu woli Ojca \\
\hline hymn Te Deum Laudamus & $\begin{array}{l}\text { śpiew na chwałę Pana Boga, na wzór świętych, oddających } \\
\text { chwałę Majestatowi Boskiemu }\end{array}$ \\
\hline $\begin{array}{l}\text { Laudesy } \\
\text { śpiew lub recytacja }\end{array}$ & pamiątka chwalebnego Zmartwychwstania \\
\hline benedykcja & spojrzenie Chrystusa na Piotra, po jego zaparciu się \\
\hline droga z jutrzni & $\begin{array}{l}\text { rozejście się „złych ludzi”, którzy uwięzili Jezusa: „wtrącili (...) } \\
\text { do piwnicy dla przespania” (s. 54) }\end{array}$ \\
\hline wstanie na rozmyślanie & Jezus wyprowadzony „z piwnicy”. Rozważanie Jego cierpienia \\
\hline Prima & Jezus na sądzie Piłata i Heroda, wzgardzenie \\
\hline $\begin{array}{l}\text { Regi seculorum (hymn } \\
\text { Regi autem saeculorum } \\
\text { immortali invisibili soli deo } \\
\text { honor et gloria in saecula } \\
\text { saeculorum amen alleluia) }\end{array}$ & $\begin{array}{l}\text { oddanie Bogu chwały za „wielką zelżywość i sromotę [wstyd, } \\
\text { hańbę] Jego" (s. 56) }\end{array}$ \\
\hline
\end{tabular}




\begin{tabular}{|c|c|}
\hline kolenda & $\begin{array}{l}\text { męczeństwo i cnota świętych; Jezus stojący na sądzie Heroda } \\
\text { „sędziowie niesprawiedliwi siedzieli” (s. 56) }\end{array}$ \\
\hline Deo Gratias & wyprowadzenie Jezusa \\
\hline Sancta Maria & smutek Maryi patrzącej na Jezusa w „,szyderskiej szacie” (s. 57) \\
\hline $\begin{array}{l}\text { Deus in adiutorium, } \\
\text { odmawiane } 3 \text { razy (Ps } \\
\text { 70, rozpoczynający każdą } \\
\text { godzinę oficjum: Deus in } \\
\text { adiutorium meum intende, } \\
\text { Domine ad adiuvandum me } \\
\text { festina) }\end{array}$ & $\begin{array}{l}\text { prośba Trójcy Świetej o odpuszczenie grzechów „przeszłych, } \\
\text { mniejszych i w któreśmy mogli wpaść nieostrożnie” (s. 58) }\end{array}$ \\
\hline pacierz & Jezus związany upada przed Herodem \\
\hline $\begin{array}{l}\text { kapitulum (fragment lekcji } \\
\text { recytowanej po psalmach) }\end{array}$ & u Piłata - naleganie Żydów na skazanie na śmierć Jezusa \\
\hline Tercja & cierniem ukoronowanie i „naśmiewiska” \\
\hline Sexta & droga krzyżowa, upadki Jezusa pod krzyżem \\
\hline Nona & polecenie Piłata ukrzyżowania Jezusa między łotrami \\
\hline Nieszpory & $\begin{array}{l}\text { zdjęcie Jezusa z krzyża przez Nikodema i Józefa, którzy całowali } \\
\text { Jego rany }\end{array}$ \\
\hline Kompleta & $\begin{array}{l}\text { pogrzeb Jezusa; myślenie o własnym pogrzebie, polecanie duszy } \\
\text { Bogu }\end{array}$ \\
\hline $\begin{array}{l}\text { Salve Regina (antyfona ku } \\
\text { czci Maryi: Salve, Regina, } \\
\text { Mater misericordiae, vita, } \\
\text { dulcedo, et spes nostra, } \\
\text { salve.... }\end{array}$ & wdzięczność dla Maryi za urodzenie Zbawiciela \\
\hline
\end{tabular}

Źródło: opracowanie własne na podstawie Dyrekcja zakonnego życia.

Każda z części liturgii godzin miała swoje odniesienie w sferze symbolicznej, choć rozbudowany ,wykład” przygotowano tylko dla jutrzni z laudesami, wraz z symbolicznym znaczeniem poszczególnych elementów (,wykładem pacierzy kapłańskich"). Godziny dzielono na dwa nokturny, którym odpowiadały określone psalmy i responsoria, fragmenty Biblii oraz modlitwy. Przed jutrznią nowicjuszki powinny odmówić specjalną modlitwę. Rozpoczynało ją wezwanie zaczerpnięte z psalmu 51 Domine labia mea aperies et os meum adnuntiabit laudem tuam („Otwórz Panie usta moje na błogosławienie Imienia Twego świętego”), które jednocześnie rozpoczynało całodzienny cykl godzin kanonicznych. Następnie siostry prosiły o oczyszczenie serca z wszelkich ,próżnych, przewrotnych i błąkających się myśli" ${ }^{4}$. Oprócz skupienia potrzebne było „oświecenie rozumu” oraz „zapalenie afektów”, czyli przygotowanie się na „godne, pilne i nabożne” odprawienie oficjum, które odbywało się w obecności Boga.

${ }^{44}$ Dyrekcya zakonnego, s. 84. 
W poszczególnych częściach jutrzni zastosowano następującą symbolikę:

Początek jutrzni: venite (Ps 94 Venite exsultemus) - pożegnanie Jezusa z Maryją hymn - odejście Jezusa do Wieczernika.

Nokturn pierwszy: psalm 1 - ustanowienie Najświętszego Sakramentu; psalm 2 - zapowiedź zdrady Judasza (należało wtedy rozmyślać o „strwożeniu Apostołów”); psalm 3 - cierpienie Jezusa i smutek Apostołów; Gloria Patri [doksologia Gloria Patri, et Filio, et Spiritui sancto. Sicut erat in principio, et nunc, et semper et in saecula saeculorum, Amen, odmawiana na końcu psalmów] oznaczała wdzięczność za ustanowienie Eucharystii; pacierz - zapowiedź zaparcia się św. Piotra; Exaudi (Ps 26,1 Exaudi, Domine, vocem meam, qua clamavi ad te: adiutor meus esto, ne derelinquas me, neque despicias me, Deus salutaris meus i błogosławieństwo przed lekcją) i benedykcja - obietnica św. Piotra pójścia za Jezusem na śmierć; lekcja 1 - Chrystus wstaje od stołu; responsoria - „Nogi umywał Apostołom"; lekcja 2 - św. Piotr wzbrania się przed umyciem nóg; responsoria „Uniżenie Pana Jezusa do nóg Judaszowych”; lekcja 3 - cierpienie Jezusa w trakcie mycia nóg Judaszowi; responsoria - zalecenie wzajemnej miłości.

Nokturn drugi: psalm 1 - odejście Jezusa do Ogrójca; psalm 2 - przejście na modlitwę; psalm 3 - budzenie uczniów; pacierz - Jezus oddala się na modlitwę; lekcja 1 - krwawy pot; responsoria - cierpienie Jezusa z powodu daremności dla wielu jego Męki; lekcja 2 - drugie budzenie uczniów; responsoria - odejście Jezusa na modlitwę; lekcja 3 - anioł z kielichem, pełnienie woli Ojca; responsoria informowanie uczniów o zbliżaniu się Judasza.

Nokturn trzeci: psalm 1 - boleść Jezusa; psalm 2 - pytanie „kogo szukacie”, odpowiedź Jezusa Nazareńskiego; psalm 3 - odpowiedź: Jam jest; pacierz - „upadli wszyscy na ziemię"; lekcja 1 - zamieszanie przy wejściu tłumu do Ogrójca; responsoria - pytanie Piotra dotyczące obrony Jezusa; lekcja 2 - ucięcie ucha i uzdrowienie „Malchusa”; reponsoria - Judasz całuje Jezusa; lekcja 3 - Jezus pyta Judasza, po co przyszedł, Judasz wydaje Go pocałunkiem; Te Deum Laudamus (Te Deum laudamus: Te Dominum confitemur Te aeternum Patrem omnis terra veneratur, hymn odmawiany zamiast dziewiątego responsorium) - nowicjuszka miała „u nóg Pana Jezusa” dziękować za „tak wielki wykup”45.

Poszczególne elementy porządku oficjum „wprowadzały” nowicjuszkę w przestrzeń ewangelicznych wydarzeń: od Wieczernika po Ogród Oliwny. Nawiązanie do wszystkich epizodów budowało pewien rytm współuczestniczenia (compasio) w Męce Pańskiej. Najwyraźniej taki sposób przeżywana jest widoczny w przypadku laudesów. Tu należało wyobrazić sobie, jak Jezus był przewrócony, skrępowany, ,zepchnięty z mostu” do potoku Cedronu, jak rozbił brodę o kamień, był „po błotach włóczony”, spoliczkowany u Annasza i Kajfasza, opluty, zdradzony przez św. Piotra ${ }^{46}$. Poszczególne obrazy biblijne nawiązują przy tym do ćwiczeń ignacjańskich, zwłaszcza z tygodnia trzeciego. Konsekwencją rozważania była modlitwa do Jezusa jako Baranka Bożego, który jest „najłaskawszy i najcichszy”: nowicjuszka prosiła Go o miłosierdzie i „nadgrodzenie” (tj. wyrówna-

\footnotetext{
${ }^{45}$ Tamże, s. 95.

${ }^{46}$ Tamże, s. 95-97.
} 
nie, powetowanie) zaniedbań w czasie odprawiania godzin. Jutrznie i laudesy kończyła modlitwa, którą nowicjuszka, gdy uznała za „oziębłą i roztargnioną”, mogła prosić Boga o jej poprawienie i udoskonalenie ${ }^{47}$.

Sposób przeżywania liturgii, podobny do zalecanego w Dyrekcji zakonnego $\dot{z} y c i a$, był znamienny dla św. Gertudy. Całe życie w klasztorze pojmowała ona jako życie modlitwy, podejmowanej ,sercem i umysłem”, skoncentrowanym na Chrystusie. Każdą czynność odnosiła do życia Chrystusa, którego mniszki miały przyjąć za najdoskonalszy wzór postępowania. Przykładowo w trakcie kropienia wodą święconą Dyrekcja zakonnego życia zalecała (za naukami św. Gertudy), by mówić: „przez kroplę krwi Twojej Panie Jezu Chryste i przez moc męki, obmyj mię od wszelkiej zmazy i oczyść mię od wszelkiego grzechu"48.

Nabożeństwa i modlitwy, charakterystyczne dla zwyczajów w konkretnym klasztorze, uzupełniały liturgię godzin. W Pektoraliku duchownym Ch. Zdrowski uznał, że „wszelkie usprawiedliwienie i zbawienie” człowieka pochodzi od Męki Chrystusowej, zalecał zatem, by po oficjum wielkim i oficjum Parvum odprawić godzinki pasyjne. W Dyrekcji zakonnego życia również zaproponowano nowicjuszkom „Godziny Męki Pańskiej”. O wyznaczonym czasie należało skoncentrować uwagę na wydarzeniach opisywanych w Ewangeliach ${ }^{49}$. Takie rozważania, upamiętniające wydarzenia ewangeliczne, są także charakterystyczne dla drogi krzyżowej, polegającej na symbolicznym przejściu trasy Męki Pańskiej, ułożonej w cykl tzw. stacji. Istota tego nabożeństwa wymaga od postępowania każdego dnia za Chrystusem, „niesienia krzyża życiowych zadań i doświadczeń” ${ }^{50}$.

Ta duchowa pielgrzymka miała na celu nie tylko pokutę, lecz także współuczestniczenie w cierpieniu Chrystusa, zadośćuczynienie za przewiny, dziękczynienie oraz możliwość uzyskania nadanych odpustów ${ }^{51}$. O zależnościach obu rodzajów nabożeństw świadczy „Akt mimo kościoła idąc”, zamieszczony po

${ }^{47}$ Tamże, s. 110-111.

${ }^{48}$ „Gdy się święconą wodą kropisz”, w: Gertuda św., Niebo na Ziemi Przy Swiętey z Bogiem konwersacyi Tyle gwiazdami, ile Modlitwami Ozdobione albo Modlitwy S. Gertrudy Wszelkiego wieku, stanu, y kondycyi ludziom służace z Łacińskiego ięzyka na Polski przez pewna osobę duchowna przettumaczone. Brunsbergae: Drukarnia Collegium Societatis Jesu, 1760, s. 20.

${ }^{49}$ Kolejność wg Dyrekcji zakonnego życia (s. 30-41): 19 - umycie nóg w Wieczerniku, ustanowienie Eucharystii; 8 - mowa do Apostołów, przygotowująca do męki; 9 - droga do Ogrójca, lęk i smutek Jezusa; 10 - prośba w Ogrójcu o „oddalenie kielicha”; 11 - krwawy pot; 12 - pojmanie w Ogrójcu; 1 - uderzenie u Annasza; 2 - oskarżenie u Kajfasza; 3 - zaparcie się św. Piotra; 4 - wyszydzanie w więzieniu; 5 - sąd u Kajfasza i wydanie na śmierć; 6 - sąd u Piłata; 7 - droga do Heroda; 8 - uwolnienie Barabasza; 9 - biczowanie, cierniem koronowanie; 10 - Ecce Homo; 11 - droga krzyżowa; 12 - ukrzyżowanie; 13 - modlitwa Chrystusa na krzyżu; 14 - oddanie Maryi za matkę; 15 - śmierć na krzyżu; 16 - przebicie boku włócznią; 17 - zdjęcie z krzyża; 18 - złożenie do grobu.

${ }^{50}$ J.J. Kopeć, Droga krzyżowa kontemplacją mądrości krzyża i paschalnej ofiary Jezusa Chrystusa, w: Materiały z sympozjum, http://www.kkbids.episkopat.pl/uploaded/A25/I\%20DROGA. pdf. Por. tenże, Droga Krzyżowa. Dzieje nabożeństwa i antologia współczesnych tekstów, Poznań 1987, s. 77-79.

${ }^{51}$ Więcej na ten temat zob. W. Smereka, Studium pasyjne. Rys historyczny i teksty Drogi Krzyżowej, Kraków 1968. 
„Godzinach Męki Pańskiej”. Zawierał on wezwania, zwykle powtarzane przed każdą ze stacji: „Kłaniam Ci się Panie Jezu i błogosławię Tobie...”. Tekst uzupełniała modlitwa za zmarłych (,Wieczne odpoczywanie...”) oraz odmawiane w konkretnych intencjach „pacierze”. Pierwsze pięć ofiarowano za papieża i Kościół Boży, z prośbą o nawrócenie „heretyków” i grzeszników, za przełożonych zakonu, a także w intencji zgody w ojczyźnie, za króla, jego radę i rycerstwo oraz dobrodziejów. Kolejne trzy pacierze, odmawiane po komplecie, również poświęcono dobrodziejom, przyjaciołom i powinowatym, proszono także o przebaczenie „niedbałości przy służbie Bożej”52.

Oprócz modlitwy wspólnotowej w Dyrekcji zakonnego życia omawiano także sposób indywidualnego nabożeństwa. Jednym z najważniejszych sposobów wewnętrznego ćwiczenia była medytacja, która powinna być prowadzona ,porządnie, spokojnie i pożytecznie i według każdej pojęcia"53. W Porządku nowicjatu przewidziano na nią godzinę (od 5 do 6). Mistrzyni uczyła sposobu rozmyślania, sprawdzała sposób przygotowania do niego (tematykę, tzw. punkty, przydzielała po komplecie), precyzowała, co nowicjuszka w rozmyślaniu ma „,rozumem upatrować”, jaki cel chce osiągnąć („A pożytki rozmyślania i znak ich jest wnętrzna pokora, znak pokory wnętrznej powolność z miłości Bożej ustawiczna"s4) i jakie przeszkody pokonać, uczyła także wyboru modlitwy kończącej ćwiczenie. Przyjęty sposób medytacji był nastawiony przede wszystkim na pracę intelektu ${ }^{55}$. Przygotowanie do niej polegało na przyjęciu postawy pokory i zwróceniu uwagi na wagę materii, którą wybrano do rozważania, a zwłaszcza na poczuciu obecności Boga. Po ćwiczeniu należało przypomnieć sobie jego przebieg oraz zanotować „okoliczności i pożytki duchowne”.

W Dyrekcji zakonnego życia medytację określono jako „przezwyciężenie trzech sił duszy naszej: to jest pamięci, rozumu i woli" ${ }^{56}$. Sposób prowadzenia rozmyślań był zgodny z układem proponowanym w ćwiczeniach św. Ignacego. W Dyrekcji zakonnego życia poprzedzała je modlitwa o odprawienie rozmyślań na chwałę Boga, przy czym była ona wypowiadana wraz z wyobrażeniem obecności Boga, jakby patrzącego na nowicjuszkę. Następnie uczono przeprowadzenia trzech przygotowań do rozważania. W pierwszych należało przypomnieć sobie wydarzenie biblijne, które miało być podstawą medytacji. W drugim zalecano wyobrażenie sobie miejsca, w którym „działa się tajemnica”, co miało pomagać skupieniu, w trzecim należało prosić Boga o łaskę, której chciano dostąpić. W ten sposób należało np. przypomnieć sobie scenę z Ewangelii o narodzeniu Chrystusa, wyobrazić sobie okoliczności, a wreszcie prosić o poczucie radości z Narodze-

${ }^{52}$ Dyrekcyja zakonnego, s. 44-45.

${ }^{53}$ Porzadek nowicjatu, s. 186.

${ }^{54}$ Tamże, s. 187.

${ }^{55} \mathrm{O}$ znaczeniu medytacji i konkretnych lekturach związanych ze szkołą ignacjańską, karmelitańską i salezjańską zob. J. Gwioździk, Literatura medytacyjna w środowisku żeńskich klasztorów kontemplacyjnych w XVII wieku. Kanon - obieg - style odbioru, w: Drogi duchowe katolicyzmu polskiego XVII wieku, red. A. Nowicka-Jeżowa, Warszawa 2016, s. 394-419.

${ }^{56}$ Dyrekcya zakonnego, s. 45 
nia lub o pragnienie naśladowania pokory i ubóstwa Chrystusa $^{57}$. Teksty pasyjne dzielono także zgodnie z układem dnia na tzw. przybytki. Pierwszy (do nieszporów) był poświęcony na medytację mądrości Bożej (obraz cierniem koronowania), drugi (od nieszporów do obiadu) koncentrował się na miłosierdziu Bożym (wyobrażenie ran na nogach Chrystusa), trzeci (od obiadu do komplety) polegał na rozważaniu posłuszeństwa Chrystusa (symbolizowały je rany Jego rąk), czwarty (od komplety do litanii) uświadamiał cierpliwość Bożą (rany zadane w plecy), a piąty (od litanii do przebudzenia) służył uświadomieniu sobie miłości Oblubieńca (rana w boku) ${ }^{58}$. Specjalny czas obowiązywał w okresie Wielkiego Postu. Wówczas w Dyrekcji zakonnego życia proponowano praktykę pokutną, którą można było ofiarować w intencji osób potrzebujących pomocy. Zachowywano zatem całkowite milczenie w określone dni tygodnia, na pamiątkę słów wypowiadanych przez Chrystusa na krzyżu ${ }^{59}$.

Część tekstu Dyrekcji zakonnego życia została przygotowana zgodnie z metodą proponowaną w Porzadku nowicjatu, dołączonym do tzw. reguły reformowanej z 1606 r. Stamtąd pochodzi tzw. Rozmowa duchowna. Stanowiła ona czwarty ze sposobów duchowego ćwiczenia nowicjuszek (w okresie 6 miesięcy) ${ }^{60}$. Były dwie metody prowadzenia rozmowy. Po pierwsze mistrzyni nowicjuszek każdego dnia wyznaczała dwie panny, które miały przygotować temat rozmowy, zgodny z prowadzonym rozmyślaniem lub lekturą. Następnie każda nowicjuszka relacjonowała swój sposób pojmowania poruszanych zagadnień. W ten sposób sprawdzano stopień jej przygotowania do życia duchowego i postępu w dążeniu do doskonałości. Po drugie wyznaczona nowicjuszka zadawała innym pytania i kontrolowała poprawność odpowiedzi. Pytania dotyczyły powinności wobec Boga i wspólnoty oraz cnót osobistych. Cztery przykłady takich rozmów zostały przedrukowane w Dyrekcji zakonnego życia ${ }^{61}$. Wymieniono w niej następnie cnoty św. Benedykta, które w poszczególnych miesiącach roku powinny naśladować jego duchowe córki. Kolejno w każdym dniu tygodnia nowicjuszki powinny starać się „ćwiczyć” określoną postawę, np. trwanie w obecności Bożej, pełnienie woli Bożej, gorliwość w dążeniu do doskonałości, dbanie o unikanie gniewu, beznadziei i smutku, by osiągnąć wewnętrzny pokój (pax benedictina).

Podstawą proponowanej w Dyrekcji zakonnego życia postawy nowicjuszek było „wyniszczenie samej siebie i wyrzeczenie się własnej woli”'62. Ten model ascezy był realizowany w klasztorze ukształtowanym jako benedyktyńska szkoła służby Bożej (schola servitii Dei). Życie nowicjuszek wypełniała przede wszystkim modlitwa wspólnotowa i indywidualne nabożeństwa oraz praktyki ascetyczne, z którymi zapoznawano się w trakcie prowadzonej w nowicjacie formacji. Intelektualne uzasadnienie podejmowanych działań było zgodnie z ideałami kongregacji chełmińskiej, czyli chodziło o podejmowanie „stałej pracy nad zwracaniem myśli,

\footnotetext{
${ }^{57}$ Tamże, s. 47-48.

${ }^{58}$ Tamże, s. 136-140.

${ }^{59}$ Tamże, s. 141-145.

${ }^{60}$ Porzadek nowicjatu, s. 208-216.

${ }^{61}$ Tamże, s. 210-216.

${ }^{62}$ Tamże, s. 1.
} 
a przez myśli i serca, do Boga"63. Jednocześnie ksieni J.S. Reytanówna odwoływała się do nauk i zwyczajów modlitewnych, propagowanych przez dawnych spowiedników konwentu, zwłaszcza przez benedyktyna tynieckiego i przeora w Starych Trokach Ch. Zdrowskiego. Wykorzystywała ponadto teksty innych autorów ascetycznych, w konwencie wileńskim najprawdopodobniej uznane za szczególnie ważne $\mathrm{w}$ realizacji powołania zakonnego. W konsekwencji powstało unikalne kompendium, mające na celu pomoc w formacji zakonnej, a jednocześnie ukazujące sposób ujęcia ideału życia mniszego w wileńskiej wspólnocie.

\section{REFERENCES / BIBLIOGRAFIA}

\section{Źródla}

Alvarez Jakub, O żywocie zakonnym jako ma być świętobliwie prowadzon. Kraków: Drukarnia Mikołaja Loba, 1613.

Dyrekcya zakonnego życia, [b.m.w., b.w.], 1744.

Gertuda św., Niebo na ziemi albo strzeliste akty $i$ afekty. W Wilnie : [b.w.], 1724.

Gertuda św., Niebo na Ziemi Przy Swiętey z Bogiem konwersacyi Tyle gwiazdami, ile Modlitwami Ozdobione albo Modlitwy S. Gertrudy Wszelkiego wieku, stanu, y kondycyi ludziom stużace z Lacińskiego ięzyka na Polski przez pewna osobę duchowna przettumaczone. Brunsbergae : Drukarnia Collegium Societatis Jesu, 1760.

Kazanie na dzień Wielkiego Patriarchy i Fundatora S. Benedykta Na rekwizyzję wielkiej honoru S. Oyca Promotorki [...] Sybilli Reytanowny Zakonu S. O. Benedykta Xieni konwentu wileńskiego do druku podane. W Wilnie : W Drukarni Akademii Societatis Jesu, 1745 .

Kiełczewski Gabriel, Sposób życia Panien do zakonu się mających : wedtug Reguły Augustyna Świętego [b.m.w., b.w.], 1613.

Porzadek nowicjatu z Reguly S. Benedykta zebrany i sporządzony do ćwiczenia duchownego i powierzchnego na ośm części główne rozdzielony, w: Reguła Świętego Oyca Benedicta. : Z łacińskiego przetlumaczona, y z Reformacya porzadków, chetmieńskiego, Toruńskiego, Żarnowieckiego, Nieświeskiego, y inszych wszytkich w Krolestwie polskim teyźe Reformacyey y Reguty S. Benedikta, ktore teraz sa y napotym ziednoczone będa, Klasztorow Panieńskich. Władza stolice apostolskiey, przez Jasnie Wielmożnego Oyca, X. Wawrzynca Gębickiego, z taski Bożey Biskupa Chetmieńskiego, Pomezaniey administratora etc.Roku pań. 1605 potwierdzona. Na końcu położone krotko zebrane laski y odpusty przez uczestnictwo tymże Zakonnicom od ś. pamięci Clemensa PP. VIII darowane wiecznie. W Krakowie : U Wdowy Jakuba Sybeneychera, 1606.

Reguła Świętego Oyca Benedicta. Z łacińskiego przettumaczona, y z Reformacya porząków, chetmieńskiego, Toruńskiego, Żarnowieckiego, Nieświeskiego, y inszych wszytkich w Krolestwie polskim teyże Reformacyey y Reguty S. Benedikta, ktore teraz sa y napotym ziednoczone będa, Klasztorow Panieńskich. Władza stolice apostolskiey, przez Jasnie Wielmożnego Oyca, X. Wawrzynca Gębickiego, z łaski Bożey Biskupa Chetmieńskiego, Pomezaniey administratora etc.Roku pań. 1605 potwierdzona. Na

${ }^{63}$ M. Borkowska, Ideat benedyktynki proponowany przez kongregację chetmińska, „Znak”, 22 (1980), s. 1565. 
końcu położone krotko zebrane laski y odpusty przez uczestnictwo tymże Zakonnicom od ś. pamięci Clemensa PP. VIII darowane wiecznie. W Krakowie: U Wdowy Jakuba Sybeneychera, 1606.

Rozmyślania na początku ćwiczenia nowicjackiego sporządzone Roku Pańskiego 1778 dnia 1 miesiaca sierpnia Za staraniem [...] Beaty Nikorowiczówny konwentu lwowskiego WW PP Benedyktynek nowicjatu Mistrzyni, Lwowska Narodowa Naukowa Biblioteka Ukrainy im. Wasyla Stefanyka, rkps 118.

W.O. y P. Jana z Turecrematu, kardinała S. Sixta na świętego Benedikta Opata Regute wyktad. W Krakowie: W Drukarni Andrzeja Piotrkowczyka, 1607.

Wielki luminarz Benedykt święty cnotami i cudami nad słońce jaśniejszy... W Wilnie: w Drukarni Societatis Jesu, 1745.

Zabaw, cwiczenia, y niektórych Modlitw dla Panien Zakonnych krotko zebranych część pierwsza. W Krakowie : Bazyli Skalski Drukował, 1610.

Zawadzki Roman, Metal na taksie i próbie Opatrzności Boskiej siła ważąy albo moc i skutki metalu krzyża Ojca i Patriarchy Benedykta przeciwko morowemu powietrzu. W Wilnie : w Drukarni Akademickiej Societatis Jesu, 1709.

Zdrowski Chryzostom, Pektoralik Duchowny dla Panien Zakonnych Pod Reguła Swiętego Benedykta Zyiacych [...] do druku za dozwoleniem Starszych Podany. W Wilnie: w Drukarni Akademickiej Societatis Jesu, 1681.

\section{Opracowania}

Borkowska Małgorzata, Ideał benedyktynki proponowany przez kongregację chetmińska, „Znak”, 22 (1980) s. 1564-1571.

Borkowska Małgorzata, Two Attemps at Self Goverment of Femine Religious Institutes in Poland, „Studia Monastica”, 23 (1981) s. 169-179.

Borkowska Małgorzata, Potrydencka wersja Reguly św. Benedykta, w: Za przewodem Ewangelii. Profesja monastyczna, Tyniec 1986, s. 249-262.

Borkowska Małgorzata, Między tradycją a powrotem do źródeł. Szesnastowieczne modele odnowy życia zakonnego w Polsce, w: Fermentum massae mundi, red. N. Cieślińska, P. Rudziński, Warszawa 1990, s. 262-266.

Borkowska Małgorzata, Słownik polskich ksień benedyktyńskich, Niepokalanów 1996.

Borkowska Małgorzata, Życie codzienne polskich klasztorów żeńskich w XVI-XVIII wie$k u$, Warszawa 1996.

Borkowska Małgorzata, Leksykon zakonnic polskich epoki przedozbiorowej, t. 3, Warszawa 2008.

Gwioździk Jolanta, Kultura pisma i książi w klasztorach żeńskich dawnej Rzeczypospolitej XVI-XVIII wieku, Katowice 2015.

Gwioździk Jolanta, Benedyktynka doskonała (Pektoralik duchowny 1681), w: Monastycyzm XV-XVIII wieku. Tradycja średniowieczna wobec wyzwań nowożytnego humanizmu, red. M.T. Gronowski, P. Urbański, Warszawa 2016, s. 80-114.

Gwioździk Jolanta, Literatura medytacyjna w środowisku żeńskich klasztorów kontemplacyjnych w XVII wieku. Kanon-obieg-style odbioru, w: Drogi duchowe katolicyzmu polskiego XVII wieku, red. A. Nowicka-Jeżowa, Warszawa 2016, s. 394-419.

Kopeć Jerzy Józef, Droga Krzyżowa. Dzieje nabożeństwa i antologia współczesnych tekstów, Poznań 1987.

Rotter Lucyna, Ubiór czy kostium? Znaczenie i funkcja strojów zakonnych, Kraków 2015. Smereka Władysław, Studium pasyjne. Rys historyczny i teksty Drogi Krzyżowej, Kraków 1968. 


\title{
Netografia
}

Grzegorz Wielki, Komentarz do „Pieśni nad pieśniami”, w: Teologia duchowości, http:// duchowosc.uksw.edu.pl/czytelnia/gwiazda/grzegorz-wielki/ (dostęp 10.11.2018).

Kopeć Jerzy Józef, Droga krzyżowa kontemplacja mądrości krzyża i paschalnej ofiary Jezusa Chrystusa, w: Materiaty z sympozjum, http://www.kkbids.episkopat.pl/ uploaded/A25/I\%20DROGA.pdf (dostęp: 10.11.2018).

\section{"DYREKCYA ZAKONNEGO ŻYCIA" - AN UNKNOWN TREATISE FROM 1744 ON THE MONASTIC FORMATION OF BENEDICTINE NOVICE NUNS}

\begin{abstract}
In 1744, Joanna Sybilla Reytanówna, a Vilnius Benedictine abbess, published a book entitled "Dyrekcya zakonnego życia" ("Directions on Religious Life"). The tome comprises a collection of practical texts which were useful in the all-day formation of novices, hence it primarily contains specific teachings on various ways of improving life in the convent. The teachings are accompanied by appropriate prayers. The practical nature of the book can also be presumed given its small format, which means it could be read in any situation - all the more as the recommended exercises had to be performed throughout the activities planned for the entire day, following the rhythm of life in the monastery. The basic group of issues addressed in "Dyrekcya zakonnego życia" was related to specific methods of structuring the community life. The book presents a practical link between every activity and the spiritual realm, e.g. teaching distinct methods of meditation and spiritual conversation. It also provides instruction on imitating the Benedictine, virtues' broken down into separate months as well as on practising excellence (broken down into days of the week). In her treatise, Joanna Sybilla Reytanówna referred both to the formation ideals pursued in the Chełmno congregation and the teachings and prayer customs promoted by Benedictines, former convent confessors and other ascetic authors. As a result, she managed to compose a unique compendium aimed at facilitating religious formation in a convent, which, at the same time, presents the ideals of monastic life in the Vilnius community.
\end{abstract}

Keywords: Vilnius Benedictine Sisters; Joanna Sybilla Reytanówna; novitiate; religious formation 